International Journal of

Supply Chain

Management

(IJSCM)

End User Involvement on Performance of Consultative Group on International Agricultural Research Institutes in Kenya

Gerald Mutiso Maweu and Dr. Samson Nyang’au Paul

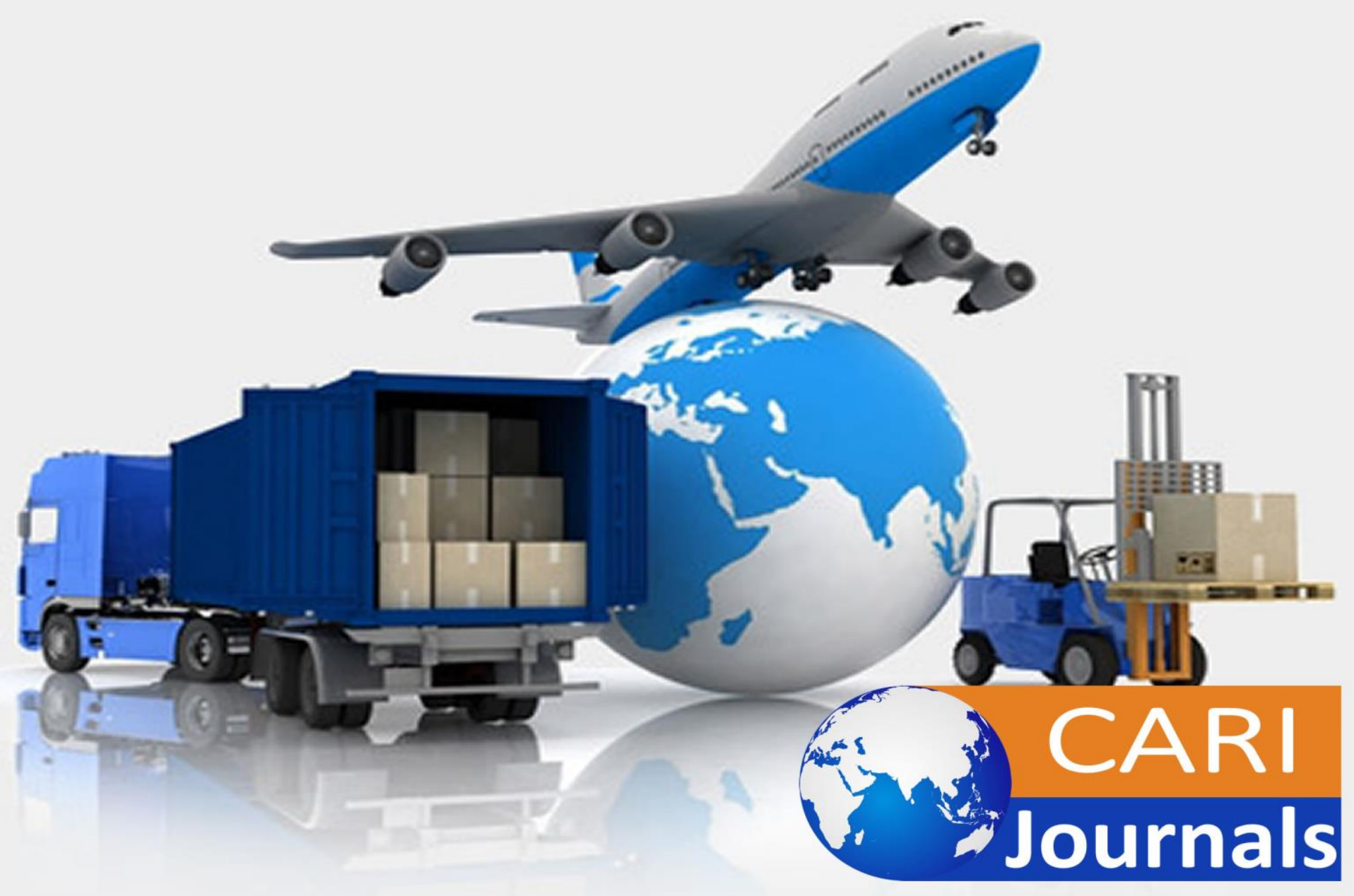




\title{
End User Involvement on Performance of Consultative Group on International Agricultural Research Institutes in Kenya
}

\author{
${ }^{1 *}$ Gerald Mutiso Maweu \\ Post Graduate Student: Department of Procurement and Logistics, \\ Jomo Kenyatta University of Agriculture and Technology \\ *Corresponding Author's E-mail: gmaweu@gmail.com \\ ${ }^{2 *}$ Dr. Samson Nyang'au Paul \\ Lecturer, Department of Procurement and Logistics \\ Jomo Kenyatta University of Agriculture and Technology
}

\begin{abstract}
Purpose: The purpose of the study was to assess the influence of end user involvement on performance of consultative group on international agricultural research institutes in Kenya.

Methodology: This research study adopted a descriptive research design approach. The researcher prefers this method because it allows an in-depth study of the subject. The target population were procurement 152 officers in the consultative group on international agricultural research institutes in Kenya. This study used census as a rule of thumb since the population of procurement officers in consultative group on international agricultural research institutes is less than 200. The study combined two methods in its data collection that is, questionnaires and key informant interviews. After data collection, quantitative data was coded using Statistical Package for Social Science (SPSS) version 20. Data was analyzed through descriptive statistical methods such as means, standard deviation, frequencies and percentage. Inferential analyses were used in relation to correlation analysis and regression analysis to test the relationship between the four explanatory variables and the explained variable
\end{abstract}

Results and conclusion: The findings of the study indicated that need identification phase, design phase, implementation phase and maintenance phase have a positive relationship with performance of consultative group on international agricultural research institutes in Kenya.

Unique contribution to theory, policy and practice: The study recommended that institutions should embrace need identification phase, design phase, implementation phase and maintenance phase so as to improve performance of consultative group on international agricultural research institutes and further researches should to be carried out in other institutions to find out if the same results can be obtained.

Keywords: Need identification phase, design phase, implementation phase and maintenance phase 
International Journal of Supply Chain and Logistics

ISSSN 2520-3983 (Online)

Vol. 4, Issue No.1, pp 70 - 92, 2020

$\underline{\text { www.carijournals.org }}$

\subsection{INTRODUCTION}

End user involvement in specifications development in the private sector has consistently been poor hindering the realization of sustainable economic growth and development since the country attained her independence. Among the noted factors that contribute to poorly met procurement performance targets included; inadequate supplier relationship strategies, excessive regulations and controls, frequent political interference, poor management, outright mismanagement of resources and lack of a guiding vision (Dean \& Kiu, 2012).

According to Lazear (2010) end user involvement in specifications development refers to a process in which an explicit set of requirements to be satisfied by a material, product, or service is given by a buyer to the supplier. This is also a fair process for suppliers to ensure they are quoting on a like-for-like basis. When developing specifications, it is important to distinguish between product requirements and product preferences and build in tolerances for suppliers to adhere to and not to restrict supply and build cost into a product (Ngugi \& Mugo, 2012).

Lack of clear focus as to what is expected from contractors and poor or no methods of measuring performance has been the greatest challenge (Mohan, 2010). Many private entities decided to manage private sector through end user involvement in specifications development to address the situation. According to Lazear (2010) end user involvement in specifications development refers to a process in which an explicit set of requirements to be satisfied by a material, product, or service is given by a buyer to the supplier(s). This is also a fair process for suppliers to ensure they are quoting on a like-for-like basis.

When developing specifications, it is important to distinguish between product requirements and product preferences and build in tolerances for suppliers to adhere to and not to restrict supply and build cost into a product (Ngugi \& Mugo, 2012). End user involvement in specifications development originated in France. It was later developed with great deal of elaboration in Pakistan and Korea and thereafter introduced to India. It has been adopted in developing countries in Africa, including Nigeria, Gambia, Ghana to mention just a few (Ngyao \& Yip, 2009).

\subsection{Problem Statement}

In many emerging economies especially in Asia, the not for profit industry had been the economic growth engine through various food security programs (Rotich, 2011). However, Kenya's not for profit industry enjoyed modest growth rates averaging 4\% over the last decade (NGO'S coordination board, 2014). In the year 2010, agricultural not-for profit sector was the second largest sub sector of the economy after manufacturing but in 2012, it was in the fourth place behind manufacturing, wholesale and retail trade (World Bank, 2013).

Kenya's Vision 2030 emphasizes the need for appropriate not for profit strategy for efficient and sustainable practices as a way of making the country globally competitive and a prosperous nation (KNBS, 2008). Nevertheless, consultative group on international agricultural research institutes in Kenya operate at a technical efficiency of about 59\% compared to their counterparts in South Africa at $70 \%$ and Malaysia at about $74 \%$ hence end user involvement may help to close this gap. 
International Journal of Supply Chain and Logistics

ISSSN 2520-3983 (Online)

Vol. 4, Issue No.1, pp 70 - 92, 2020

www.carijournals.org

According to a report by Deloitte (2012) on consultative group on international agricultural research institutes in South Africa, end user involvement saved various firms over Kshs. 70 Billion in the financial year (FY) 2011/2012. The report also reveals that the life span of consultative group on international agricultural research institutes is getting smaller, winding up at notable percentage indices, fluctuating between $49 \%, 54 \%$ and $58 \%$ respectively; poor end user involvement was cited as the main reason.

The agricultural not-for profit sector has always accounted for 30\% of the country's Gross Domestic Product (GDP), provided employment to about 600,000 people in the formal sector and 2 million persons in the informal sectors of the economy, however they have been experiencing problems in the performance of their production and operations management (USAID, 2012).

In Kenya, studies have reported mixed findings with regard to end user involvement and its influence on firm performance, for instance, a study by Mathenge and Dihel (2011) on the role of end user involvement in reforming East Africa's Community found that firms in Kenya are faced with challenges of measuring the performance of their acquisitions because they are not able to anticipate and adequately meet the requirements.

A study by Ngonela, Mwaniki and Namusonge (2014), on end user involvement on tea processing firms in Bomet County found out that end user involvement reduces costs, reduce risks and gain competitive advantage. While much research has focused on the problems facing end user requirements generally in organizations in Kenya, not much research has been done to study end user involvement and its influence on performance of consultative group on international agricultural research institutes in Kenya. It is against this backdrop; the present study sets out to investigate the influence of end user involvement on performance of consultative group on international agricultural research institutes in Kenya.

\subsection{Objectives of the Study}

i. To establish the influence of need identification phase on performance of consultative group on international agricultural research institutes in Kenya.

ii. To find out how the design phase on performance of consultative group on international agricultural research institutes in Kenya.

iii. To assess the influence of implementation phase on performance of consultative group on international agricultural research institutes in Kenya.

iv. To determine the influence of maintenance phase on performance of consultative group on international agricultural research institutes in Kenya. 
International Journal of Supply Chain and Logistics

ISSSN 2520-3983 (Online)

Vol. 4, Issue No.1, pp 70 - 92, 2020

$\underline{\text { www.carijournals.org }}$

\subsection{LITERATURE REVIEW}

\subsection{Goal Setting Theory}

Need identification is best explained by the Goal Theory which states that end users are motivated by clear goals and appropriate feedback (Aitken, Childerhouse \& Towill, 2008). That working towards a goal provides a major source of motivation. Challenging and specific goals accompanied by feedback lead to higher levels of performance in terms of delivery. The prime axiom of this theory is that specific difficult goals lead to higher performance than when end users strive to simply do their best (Artley \& Stroh, 2009).

Such goals positively affect performance of an individual and direct people's efforts and energies in a particular direction. That there was a relationship between how difficult and specific a goal was and people's performance of a task. Difficult and specific delivery goals lead to better task performance than vague and easy goals. In their research, Belz and Wuensche (2009) found out that for goals to be motivational, they should have the following characteristics: They must be specific in terms of cycle and delivery time frame.

General goals which lack specifity tend not to be motivational; that goals must be challenging to be motivational. They should not be easy that they require little effort to achieve and they should not be so difficult that they are impossible to achieve; that goals must be accompanied by feedback so that it is possible to know how well one is doing and how close is to the goal accomplishment; and that end users must accept the goals and be committed to them (Cheung, Wang \& Lo, 2014).

Need identification is premised on the tenets of goal theory in that the targets are specific based on the organization's strategic plans. They are also Measurable, Attainable, Realistic and Time bound (SMART) in nature thus offering clarity to the vendors. The targets are challenging in that they are incremental in nature hence difficulty and complexity of achieving them is raised every cycle of the delivery leading to increased performance and productivity from the vendors (Sylvia, 2008).

\subsection{End User Involvement}

\subsubsection{Need Identification Phase}

Management in any company must understand the art of obtaining products and services (Parkhe, 2013). The procurement cycle follows specific steps for identifying a requirement or need of the company through the final step of the award of the product or contract. Responsible management of public and corporate funds is vital when handling this necessary process, whether in strong or weak economic markets. The business must know it needs a new product, whether from internal or external sources. The product may be one that needs to be reordered, or it may be a new item for the company (Ngugi, 2012). 


\subsubsection{Design Phase}

There are three types of specifications; functional specifications are specifications that define the function, duty or role of the goods or services. It nominates what the goods or services are broadly required to do. Functional specifications define the task or desired result by focusing on what is to be achieved rather than how it is to be done. They do not describe the method of achieving the intended result. This enables suppliers to provide solutions to defined problems (Heinrich, 2012).

Performance specifications are specifications that define the purpose of the goods or services in terms of how influenceively it will perform, that is, in capability or performance terms. Performance is a logical extension of function. Performance specifications define the task or desired result by focusing on what is to be achieved. They do not describe the method of achieving the desired result

\subsubsection{Disposal Management}

As consultative group on international agricultural research institutes endure to experience growing burden on resources, including inadequate time and access to providers, the system must contemplate new and creative chances to expand and improve the employees (Taub \& Birch, 2009). Essential employees in consultative group on international agricultural research institutes are a single approach to concurrently build upon a foundation and improve the capacity and skills of the consultative group on international agricultural research institutes workforce.

\subsubsection{Maintenance Phase}

Preventive maintenance is done before a failure has occurred (Liu \& Yao, 2013). That task can be aimed at preventing a failure, minimizing the consequence of the failure or assessing the risk of the failure occurring. When conducting corrective maintenance, the failure has now occurred and its basically reinstating equipment functionality. To be clear, corrective maintenance can be the result of a deliberate run-to-failure strategy. A run to failure or corrective maintenance strategy only restores the function of an item after it has been allowed to fail. 


\subsection{Conceptual Framework}

\section{Independent Variables}

\section{Dependent Variable}

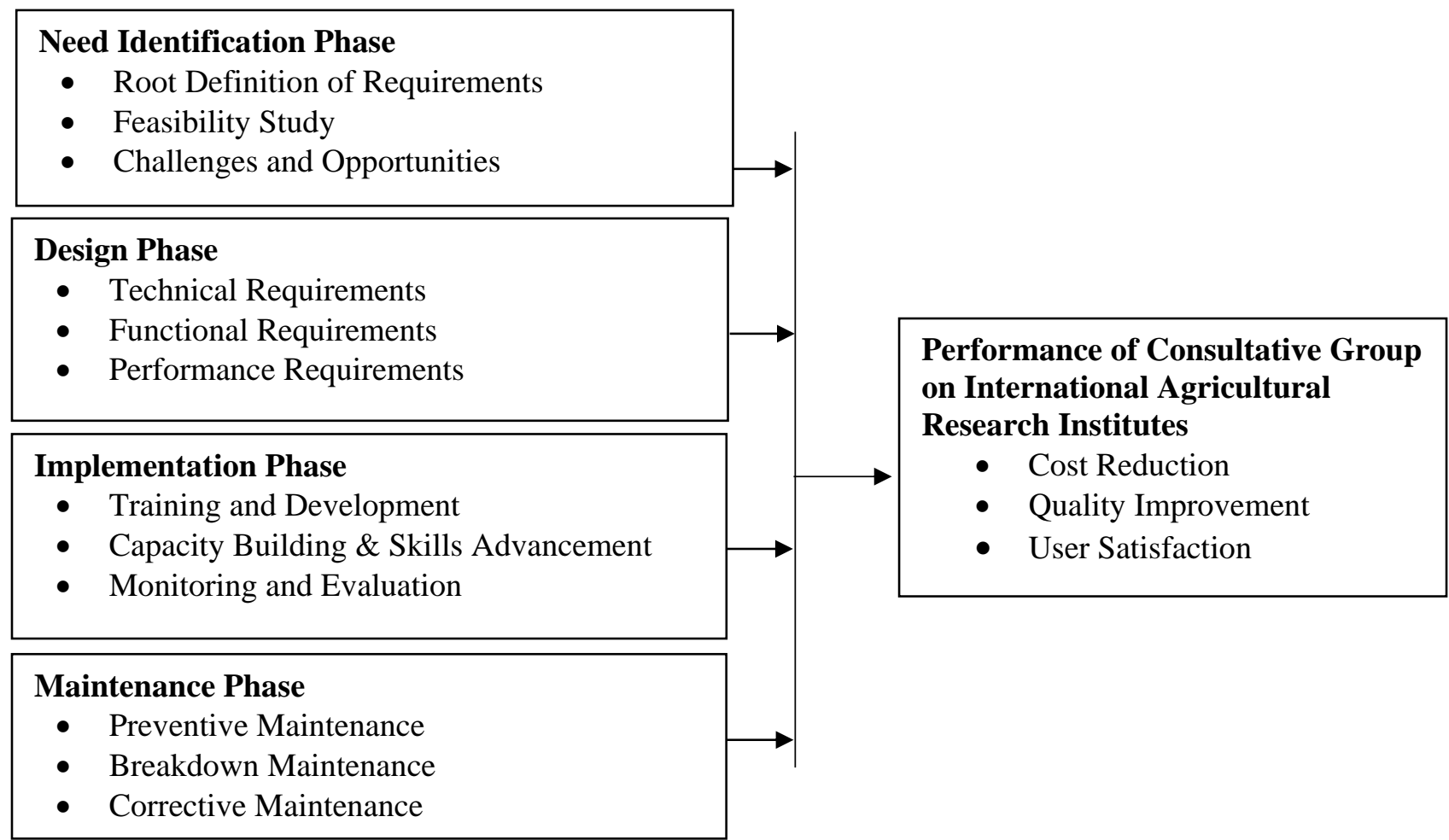

\section{Figure 1: Conceptual Framework}

\subsection{METHODOLOGY}

This research study adopted a descriptive research design approach. The researcher prefers this method because it allows an in-depth study of the subject. The target population were procurement 152 officers in the consultative group on international agricultural research institutes in Kenya. This study used census as a rule of thumb since the population of procurement officers in consultative group on international agricultural research institutes is less than 200. The study combined two methods in its data collection that is, questionnaires and key informant interviews. After data collection, quantitative data was coded using Statistical Package for Social Science (SPSS) version 20. Data was analyzed through descriptive statistical methods such as means, standard deviation, frequencies and percentage. Inferential analyses were used in relation to correlation analysis and regression analysis to test the relationship between the four explanatory variables and the explained variable 
International Journal of Supply Chain and Logistics

ISSSN 2520-3983 (Online)

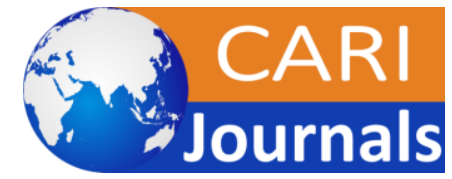

Vol. 4, Issue No.1, pp 70 - 92, 2020

www.carijournals.org

\subsection{RESULTS FINDINGS}

\subsection{Introduction}

This chapter presents results arising from the analysis of data collected using questionnaires.

\subsection{Response Rate}

A sample of respondents were interviewed using questionnaires that allowed the researcher to drop the questionnaires to the respondents and then collect them at a later date when they had filled the questionnaires. A total of 152 questionnaires were distributed to procurement officers. Out of the population covered, 104 were responsive respresenting a response rate of $68 \%$. This was above the $50 \%$ which is considered adequate in descriptive statistics according to (Kothari, 2014).

Table 1: Response Rate of Respondents

\begin{tabular}{lcc}
\hline Response & Frequency & Percentage \\
\hline Actual Response & 104 & 68 \\
Non-Response & 48 & 32 \\
Total & $\mathbf{1 5 2}$ & $\mathbf{1 0 0 \%}$ \\
\hline
\end{tabular}

\subsection{Pilot Study}

The cronbach's alpha was computed in terms of the average inter-correlations among the items measuring the concepts. The rule of thumb for cronbach's alpha is that the closer the alpha is to 1 the higher the reliability (Serekan, 2011). A value of at least 0.7 is recommended. Cronbach's alpha is the most commonly used coefficient of internal consistency and stability. Consistency indicated how well the items measuring the concepts hang together as a set. Cronbach's alpha was used to measure realibilty. This was done on the four objectives of the study. The higher the coefficient, the more reliable is the test.

Table 2: Reliability Results

\begin{tabular}{lcccc}
\hline Variable & No. of Items & Respondents & $\boldsymbol{\alpha}=$ Alpha & Comment \\
\hline Need Identification Phase & 9 & 15 & 0.893 & Reliable \\
Design Phase & 9 & 15 & 0.987 & Reliable \\
Implementation Phase & 9 & 15 & 0.974 & Reliable \\
Maintenance Phase & 9 & 15 & 0.976 & Reliable \\
\hline
\end{tabular}

\subsection{Demographic Information}

This section presents the personal details of the respondents.

\subsubsection{Distribution of Respondents by Gender}

The study determined the gender distribution of the respondents. The results were summarized in the figure below. The result in figure 2 revealed that majority of the respondents $(64 \%)$ indicated that they were male, while only $(36 \%)$ of the respondent indicated that they were female. A study on Australian international agricultural research institutes gender balance found that women and 
International Journal of Supply Chain and Logistics

ISSSN 2520-3983 (Online)

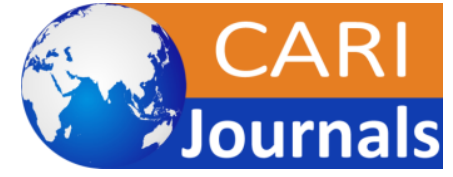

Vol. 4, Issue No.1, pp 70 - 92, 2020

www.carijournals.org

men do not differ in their ability to perform operational tasks, but rather bring a different perspective to strategic decision making (Bovis, 2012).

\section{Gender}

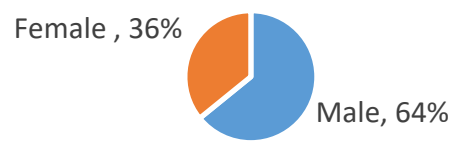

\section{Figure 2: Distribution of Respondents by Gender}

\subsubsection{Distribution of Respondents by Age}

The study determined the distribution of respondents by age. The results summarized in the table below. The results revealed that majority of the respondent (46.2\%) were above 50 years old, $(24 \%)$ were $31-40$ years old, while $(29.8 \%)$ were between $41-50$ years. The findings are in agreement with those of Hall (2014) who established that there are two natural age peaks of the early 30s and mid 40s which correlated to employee performance.

Table3: Distribution of Respondents by Age

\begin{tabular}{lcc}
\hline Years & Frequency & Percent \\
\hline $31-40$ Years & 25 & 24.0 \\
$41-50$ Years & 31 & 29.8 \\
50 Years and above & 48 & 46.2 \\
Total & $\mathbf{1 0 4}$ & $\mathbf{1 0 0 . 0 0}$ \\
\hline
\end{tabular}

\subsubsection{Distribution of Respondents by Level of Education}

The respondents were asked to state their highest level of education and the results revealed that majority of the respondent (51\%) indicated that their academic qualification was up to master's level. The result further revealed that $(49 \%)$ of the respondent indicated that their academic qualification was up to degree level. With majority respondents having degree and above, it is expected that their level of understanding of end user involvement is good. This is an indication that the results obtained from respondents interviewed in the present study can be relied upon. These findings concur those of Hatry (2016) who established that majority of who run not for profit procurement are highly educated and that there is evidence linking education and end user involvement in parastatals.

Table 4: Distribution of Respondents by Level of Education

\begin{tabular}{lcc}
\hline Education Level & Frequency & Percent \\
\hline Undergraduate & 51 & 49 \\
Post-Graduate & 53 & 51 \\
Total & $\mathbf{1 0 4}$ & $\mathbf{1 0 0}$ \\
\hline
\end{tabular}


International Journal of Supply Chain and Logistics

ISSSN 2520-3983 (Online)

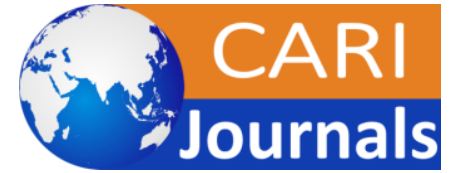

Vol. 4, Issue No.1, pp 70 - 92, 2020

www.carijournals.org

\subsubsection{Distribution of Respondents by Length of Service}

The study determined the number of years the respondents had worked in their current office. The respondents were asked to indicate their work duration. The result revealed that majority of the respondents $(31.7 \%)$ indicated that their work duration was 6-8 years. The result also showed that $(30.8 \%)$ of the respondent indicated that their work duration was 9 and above years above. The findings of the study are in tandem with literature review by Joiner (2012) who indicated that a duration and experience of employee helps him or her to have better knowledge and skills which contribute to end user involvement.

Table 5: Distribution of Respondents by Length of Service

\begin{tabular}{lcc}
\hline Length of Service & Frequency & Percent \\
\hline 3-5 Years & 39 & 37.5 \\
6-8 Years & 33 & 31.7 \\
9 Years and above & 32 & 30.8 \\
Total & $\mathbf{1 0 4}$ & $\mathbf{1 0 0 . 0}$ \\
\hline
\end{tabular}

\subsection{Descriptive Statistics}

\subsubsection{Need Identification Phase}

The first objective of the study was to assess the influence of need identification phase on end user involvement on performance of consultative group on international agricultural research institutes in Kenya. The respondents were asked to indicate to what extent did need identification phase affect end user involvement on performance of consultative group on international agricultural research institutesin Kenya. Results indicated that majority of the respondents $25 \%$ agreed that it was to a very great extent, $27 \%$ said that it was to a great extent, $35 \%$ said it was moderate, while little extent and not all were at $5 \%$ and $8 \%$ respectively.

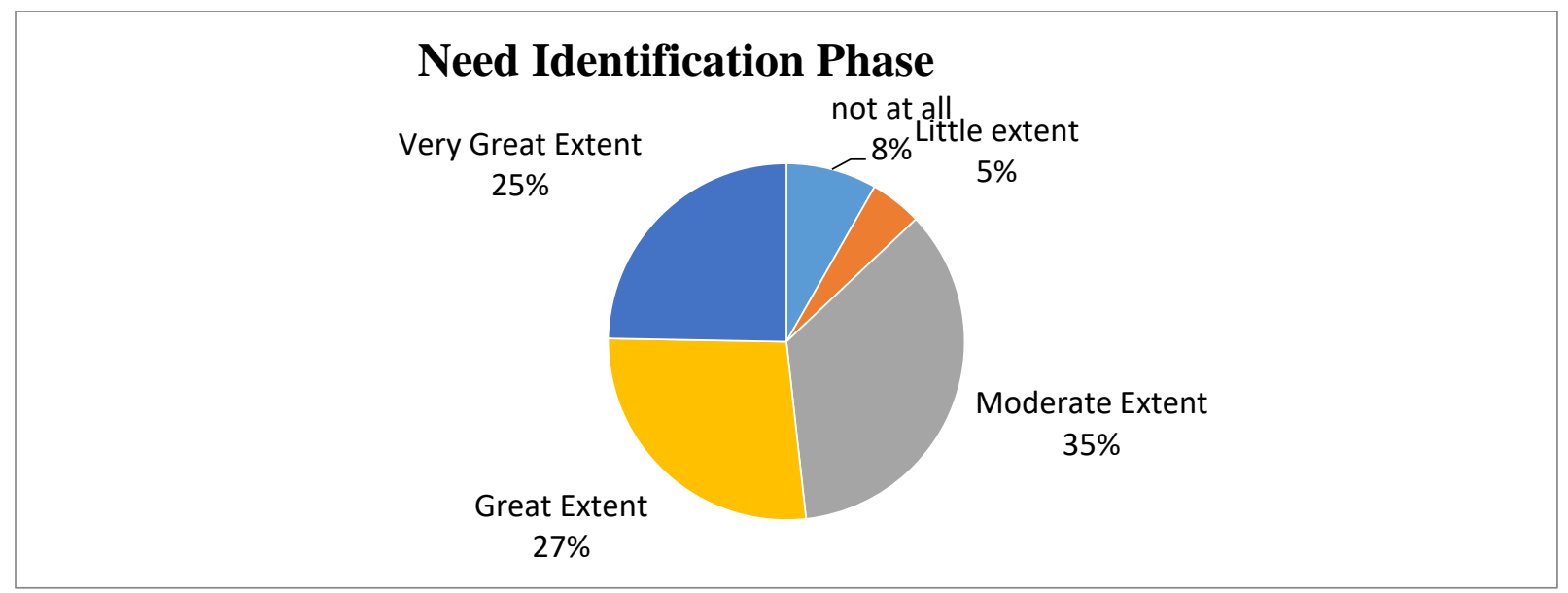

Figure 3: Need Identification Phase 
International Journal of Supply Chain and Logistics

ISSSN 2520-3983 (Online)

Vol. 4, Issue No.1, pp 70 - 92, 2020

www.carijournals.org

The respondents were also asked to comment on statements regarding need identification phase on end user involvement on performance of consultative group on international agricultural research institutes. The responses were rated on a Likert scale and the results presented in table 4.6 below. It was rated on a 5-point Likert scale ranging from; $1=$ strongly disagree to $5=$ strongly agree. The scores of 'strongly disagree' and 'disagree' have been taken to represent a statement not agreed upon. The score of 'neutral' has been taken to represent a statement agreed upon. The score of 'agree' and 'strongly agree' have been taken to represent a statement highly agreed upon.

The respondents were asked to indicate their responses on need identification phase statements. The result revealed that majority of the respondents with a mean of (3.97) agreed with the statement that Root definition of requirements plays a great role in cost reductions. The measure of dispersion around the mean of the statements was 0.947 indicating the responses were varied. The result revealed that majority of the respondent as indicated by a mean of (4.02) agreed with the statement Feasibility study plays a great role in cost reductions. The standard deviation for was 0.874 showing a variation. The result revealed that majority of the respondents (4.01) agreed with the statement that Challenges and opportunities plays a great role in cost reductions. The results were varied as shown by a standard deviation of 0.96 .

The average response for the statements on Root definition of requirements plays a great role in improving quality was (4.42). The results were varied as shown by a standard deviation of 0.701 . The average response for the statements on Feasibility study plays a great role in improving quality was (4.43). The results were varied as shown by a standard deviation of 0.529 . The results revealed that majority of the respondent with a mean of (4.41) agreed with the statement that Challenges and opportunities plays a great role in improving quality. The measure of dispersion around the mean of the statements was 0.709 indicating the responses were varied.

The result also revealed that majority of the respondent as indicated by a mean of (4.02) agreed with the statement Root definition of requirements plays a great role in improving user satisfaction. The standard deviation for was 0.874 showing a variation in the responses. The result revealed that majority of the respondent (4.16) agreed with the statement that Feasibility study plays a great role in improving user satisfaction. The results were varied as shown by a standard deviation of 0.743 . The average response for the statements on Challenges and opportunities plays a great role in improving user satisfaction was (4.35). The results were varied as shown by a standard deviation of 0.782 . The findings agree with Kingori (2012) that strictly adhering to need identification phase is a smart move and can reduce expenses significantly. 
International Journal of Supply Chain and Logistics

ISSSN 2520-3983 (Online)

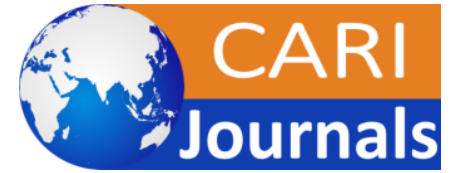

Vol. 4, Issue No.1, pp 70 - 92, 2020

www.carijournals.org

Table 6: Need Identification Phase

\begin{tabular}{lcc}
\hline Statements & Mean & Std. Deviation \\
\hline Root definition of requirements plays a great role in cost reductions & 3.97 & 0.947 \\
Feasibility study plays a great role in cost reductions & 4.02 & 0.874 \\
Challenges and opportunities play a great role in cost reductions & 4.01 & 0.96 \\
Root definition of requirements plays a great role in improving & & \\
quality & 4.42 & 0.701 \\
Feasibility study plays a great role in improving quality & 4.35 & 0.64 \\
Challenges and opportunities play a great role in improving quality & 4.43 & 0.529 \\
Root definition of requirements plays a great role in improving user & & \\
satisfaction & 4.41 & 0.709 \\
Feasibility study plays a great role in improving user satisfaction & 4.16 & 0.743 \\
Challenges and opportunities play a great role in improving user & & \\
satisfaction & 4.35 & 0.782 \\
\hline
\end{tabular}

\subsubsection{Design Phase}

The second objective of the study was to establish the influence of design phase on end user involvement on performance of consultative group on international agricultural research institutes in Kenya. The respondents were asked to indicate to what extent did design phase influence had on end user involvement. Results indicated that majority of the respondents $25 \%$ agreed that it was to a very great extent, $27 \%$ said that it was to a great extent, $35 \%$ said it was moderate, while little extent and not all were at $5 \%$ and $8 \%$ respectively.

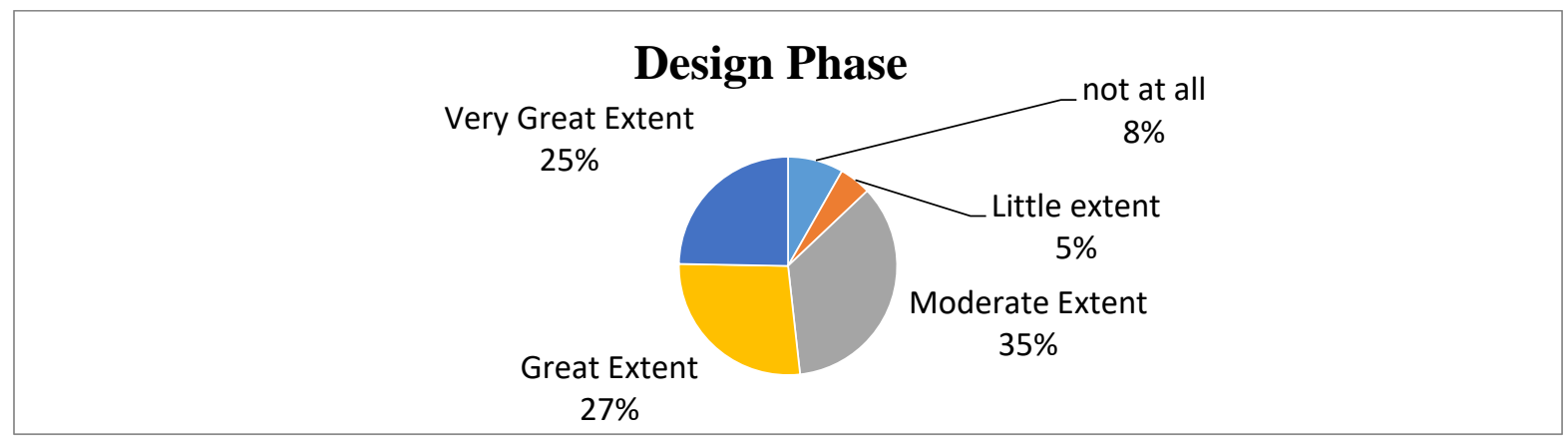

\section{Figure 4: Design Phase}

The respondents were also asked to comment on statements regarding design phase influence on end user involvement. The results revealed that majority of the respondent with a mean of (3.96) agreed with the statement that Technical requirements plays a great role in cost reductions. The measure of dispersion around the mean of the statements was 0.905 indicating the responses were varied. The result revealed that majority of the respondent as indicated by a mean of (3.95) agreed with the statement Functional requirements plays a great role in cost reductions. The standard deviation for was 0.802 showing a variation. The result revealed that majority of the respondent 
International Journal of Supply Chain and Logistics

ISSSN 2520-3983 (Online)

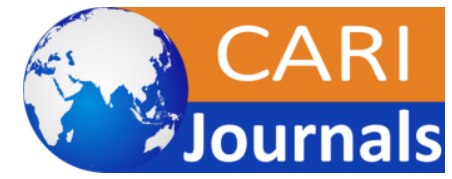

Vol. 4, Issue No.1, pp 70 - 92, 2020

www.carijournals.org

(4.49) agreed with the statement Performance requirements plays a great role in cost reductions. The results were varied as shown by a standard deviation of 0.594 .

The average response for the statements on Technical requirements plays a great role in improving quality was (4.49). The results were varied as shown by a standard deviation of 0.594 . The average response for the statements on Functional requirements plays a great role in improving quality was (4.21). The results were varied as shown by a standard deviation of 0.841 . The results revealed that majority of the respondent with a mean of (2.94) agreed with the statement Performance requirements plays a great role in improving quality. The measure of dispersion around the mean of the statements was 1.303 indicating the responses were varied.

The result revealed that majority of the respondent as indicated by a mean of (3.08) agreed with the statement Technical requirements plays a great role in improving user satisfaction. The standard deviation for was 1.347 showing a variation. The result revealed that majority of the respondent (3.57) agreed with the statement that Functional requirements plays a great role in improving user satisfaction. The results were varied as shown by a standard deviation of 1.086. The result revealed that majority of the respondent (3.55) agreed with the statement that Performance requirements plays a great role in improving user satisfaction. The results were varied as shown by a standard deviation of 1.061. These findings agree with Kipchilat (2009) that through design phase, companies can improve end user involvement.

Table 7: Design phase

\begin{tabular}{lcc}
\hline Statements & Mean & Std. Deviation \\
\hline Technical requirements play a great role in cost reductions & 3.96 & 0.905 \\
Functional requirements play a great role in cost reductions & 3.8 & 0.875 \\
Performance requirements plays a great role in cost reductions & 3.95 & 0.802 \\
Technical requirements play a great role in improving quality & 4.49 & 0.594 \\
Functional requirements play a great role in improving quality & 4.21 & 0.841 \\
$\begin{array}{l}\text { Performance requirements plays a great role in improving quality } \\
\text { Technical requirements play a great role in improving user }\end{array}$ & 2.94 & 1.303 \\
satisfaction & 3.08 & \multirow{2}{*}{1.347} \\
$\begin{array}{l}\text { Functional requirements play a great role in improving user } \\
\text { satisfaction }\end{array}$ & 3.57 & \multirow{2}{*}{1.086} \\
$\begin{array}{l}\text { Performance requirements plays a great role in improving user } \\
\text { satisfaction }\end{array}$ & 3.55 & \multirow{2}{*}{1.061} \\
\hline
\end{tabular}

\subsubsection{Implementation Phase}

There was also need to establish influence of implementation phase on end user involvement on performance of consultative group on international agricultural research institutes in Kenya as the third objective. Results indicated that majority of the respondents $47 \%$ agreed that it was to a very great extent, $45 \%$ said that it was to a great extent, $2 \%$ said it was moderate; little extent was $2 \%$ and not all at $4 \%$. 
International Journal of Supply Chain and Logistics

ISSSN 2520-3983 (Online)

Vol. 4, Issue No.1, pp 70 - 92, 2020

$\underline{\text { www.carijournals.org }}$

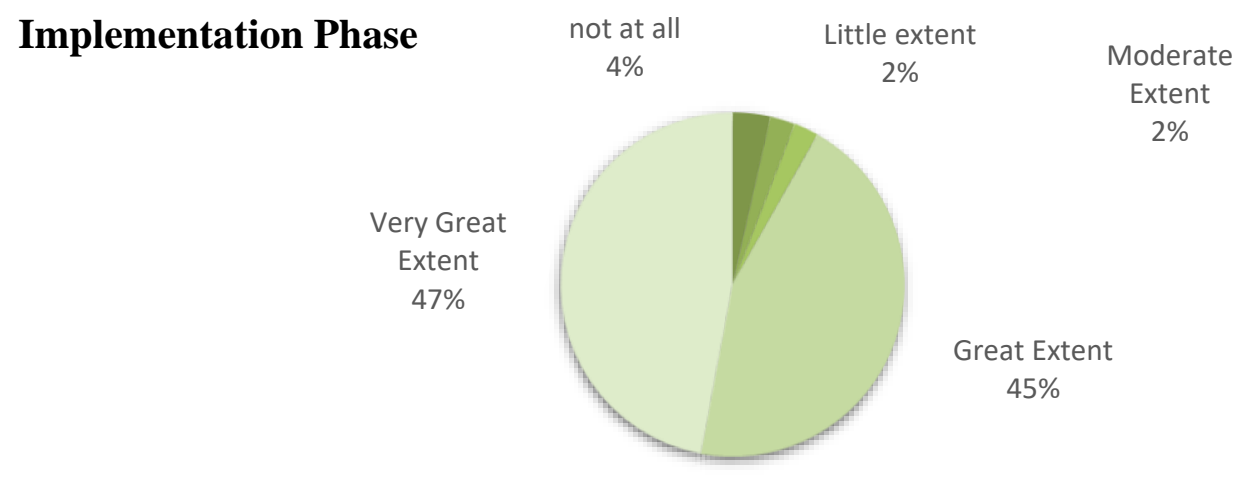

\section{Figure 5: Implementation Phase}

The respondents were asked to indicate their levels of agreement on statements regarding implementation phase. The results revealed that majority of the respondent with a mean of (3.96) agreed with the statement that Training and development of vendors plays a great role in cost reductions. The measure of dispersion around the mean of the statements was 0.947 indicating the responses were varied. The result revealed that majority of the respondent as indicated by a mean of (3.94) agreed with the statement Capacity building and skills advancement plays a great role in cost reductions. The standard deviation for was 0.946 showing a variation. The result revealed that majority of the respondent (4.01) agreed with the statement that Monitoring and evaluation plays a great role in cost reductions. The standard deviation for was 4.01 showing a variation.

The results were varied as shown by a standard deviation of 0.8 . The average response for the statements on Training and development of vendors plays a great role in improving quality was (3.94). The results were varied as shown by a standard deviation of 0.866 . The average response for the statements on Capacity building and skills advancement plays a great role in improving quality was (3.89). The results were varied as shown by a standard deviation 0.899 . The results revealed that majority of the respondent with a mean of (3.9) agreed with the statement Monitoring and evaluation plays a great role in improving quality. The measure of dispersion around the mean of the statements was 0.822 indicating the responses were varied.

The result revealed that majority of the respondent as indicated by a mean of (3.21) agreed with the statement Training and development of vendors plays a great role in improving user satisfaction. The standard deviation for was 1.413 showing a variation. The result revealed that majority of the respondents (4.44) agreed with the statement that Capacity building and skills advancement plays a great role in improving user satisfaction. The results were varied as shown by a standard deviation of 0.61 . The average response for the statements on capacity of vendors plays a great role in improving user satisfaction was (4.42). The results were varied as shown by a standard deviation of 0.588. The results are in tandem with Martini (2012) who opines that an organization benefits greatly when implementation phase processes are improved in their operations. 
International Journal of Supply Chain and Logistics

ISSSN 2520-3983 (Online)

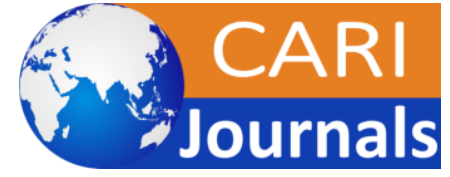

Vol. 4, Issue No.1, pp 70 - 92, 2020

www.carijournals.org

Table 8: Implementation Phase

\begin{tabular}{lcc}
\hline Statements & Mean & Std. Deviation \\
\hline Training and development play a great role in cost reductions & 3.96 & 0.81 \\
$\begin{array}{l}\text { Capacity building and skills advancement plays a great role in cost } \\
\text { reductions }\end{array}$ & 3.94 & 0.946 \\
Monitoring and evaluation play a great role in cost reductions & 4.01 & 0.8 \\
Training and development play a great role in improving quality & 3.94 & 0.866 \\
$\begin{array}{l}\text { Capacity building and skills advancement plays a great role in } \\
\text { improving quality }\end{array}$ & 3.89 & 0.899 \\
$\begin{array}{l}\text { Monitoring and evaluation play a great role in improving quality } \\
\text { Training and development play a great role in improving user }\end{array}$ & 3.9 & 0.822 \\
satisfaction & 3.21 & 1.413 \\
$\begin{array}{l}\text { Capacity building and skills advancement plays a great role in } \\
\text { improving user satisfaction }\end{array}$ & 4.44 & 0.61 \\
$\begin{array}{l}\text { Monitoring and evaluation plays a great role in improving user } \\
\text { satisfaction }\end{array}$ & 4.42 & 0.588 \\
\hline
\end{tabular}

\subsubsection{Maintenance Phase}

There was also need to establish the influence of maintenance phase on end user involvement. Results also showed that $3 \%$ of respondents indicated to very great extent, great extent was at $12 \%$, moderate extent was $37 \%$, while little extent was at $27 \%$ and not at all was at $21 \%$.

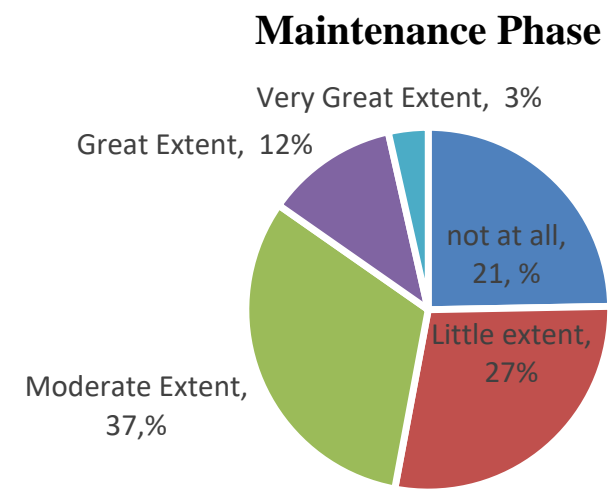

\section{Figure 6: Maintenance Phase}

The respondents were asked to indicate their views on maintenance phase. The results revealed that majority of the respondent with a mean of (4.13) agreed with the statement that Preventive maintenance plays a great role in cost reductions. The measure of dispersion around the mean of the statements was 1.035 indicating the responses were varied. The result revealed that majority of the respondent as indicated by a mean of (4.47) agreed with the statement Breakdown maintenance plays a great role in cost reductions. The standard deviation for was 0.639 showing a 
International Journal of Supply Chain and Logistics

ISSSN 2520-3983 (Online)

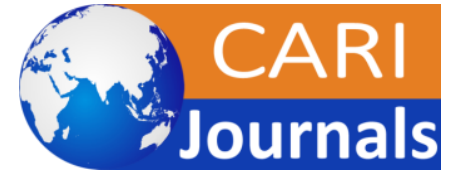

Vol. 4, Issue No.1, pp 70 - 92, 2020

www.carijournals.org

variation. The result revealed that majority of the respondent (4.32) agreed with the statement that Corrective maintenance plays a great role in cost reductions. The results were varied as shown by a standard deviation of 0.675 .

The average response for the statements on Preventive maintenance plays a great role in improving quality was (3.94). The results were varied as shown by a standard deviation of 0.866 . The average response for the statements on Breakdown maintenance plays a great role in improving quality was (4.46). The results were varied as shown by a standard deviation 0.5 . The results revealed that majority of the respondent with a mean of (4.44) agreed with the statement Corrective maintenance plays a great role in improving quality. The measure of dispersion around the mean of the statements was 0.498 indicating the responses were varied.

The result revealed that majority of the respondent as indicated by a mean of (4.44) agreed with the statement Preventive maintenance plays a great role in improving user satisfaction. The standard deviation for was 0.654 showing a variation. The result revealed that majority of the respondent (4.51) agreed with the statement that Breakdown maintenance plays a great role in improving user satisfaction. The results were varied as shown by a standard deviation of 0.501 . The average response for the statements on Corrective maintenance plays a great role in improving user satisfaction was (4.43). The results were varied as shown by a standard deviation of 0.496. The results agree with Ng'ang'a (2011) that an organization that embraces maintenance phase benefits greatly in its end user involvement operations.

Table 9: Maintenance Phase

\begin{tabular}{lcc}
\hline Statements & Mean & Std. Deviation \\
\hline Preventive maintenance plays a great role in cost reductions & 4.13 & 1.035 \\
Breakdown maintenance plays a great role in cost reductions & 4.47 & 0.639 \\
Corrective maintenance plays a great role in cost reductions & 4.32 & 0.675 \\
Preventive maintenance plays a great role in improving quality & 4.2 & 0.956 \\
Breakdown maintenance plays a great role in improving quality & 4.46 & 0.500 \\
$\begin{array}{l}\text { Corrective maintenance plays a great role in improving quality } \\
\text { Preventive maintenance plays a great role in improving user }\end{array}$ & 4.44 & 0.498 \\
satisfaction & 4.44 & 0.654 \\
$\begin{array}{l}\text { Breakdown maintenance plays a great role in improving user } \\
\text { satisfaction }\end{array}$ & 4.51 & 0.501 \\
$\begin{array}{l}\text { Corrective maintenance plays a great role in improving user } \\
\text { satisfaction }\end{array}$ & 4.43 & 0.496 \\
\hline
\end{tabular}

\subsection{Correlation Analysis}

Correlation analysis was used to determine both the significance and degree of association of the variables and also predict the level of variation in the dependent variable caused by the independent variables. The correlation summary shown in Table 4.10 indicates that the associations between each of the independent variables and the dependent variable were all significant at the $95 \%$ confidence level. 
International Journal of Supply Chain and Logistics

ISSSN 2520-3983 (Online)

Vol. 4, Issue No.1, pp 70 - 92, 2020

$\underline{\text { www.carijournals.org }}$

The correlation analysis to determine the relationship between the influence of end user involvement on performance of consultative group on international agricultural research institutes in Kenya, Pearson correlation coefficient computed and tested at 5\% significance level. The results indicate that there is a positive relationship $(\mathrm{r}=0.815)$ between need identification phase and end user involvement on performance of consultative group on international agricultural research institutes in Kenya. In addition, the researcher found the relationship to be statistically significant at $5 \%$ level $(\mathrm{p}=0.000,<0.05)$.

The correlation analysis to determine the relationship between design phase and end user involvement on performance of consultative group on international agricultural research institutes in Kenya, Pearson correlation coefficient computed and tested at 5\% significance level. The results indicate that there is a positive relationship ( $\mathrm{r}=0.605)$ between design phase and end user involvement on performance of consultative group on international agricultural research institutes in Kenya. In addition, the researcher found the relationship to be statistically significant at $5 \%$ level $(\mathrm{p}=0.000,<0.05)$.

The correlation analysis to determine the relationship between of implementation phase on and end user involvement on performance of consultative group on international agricultural research institutes in Kenya, Pearson correlation coefficient computed and tested at 5\% significance level. The results indicate that there is a positive relationship $(\mathrm{r}=0.663)$ between of implementation phase and end user involvement on performance of consultative group on international agricultural research institutes in Kenya. In addition, the researcher found the relationship to be statistically significant at $5 \%$ level $(\mathrm{p}=0.000,<0.05)$.

The correlation analysis to determine the relationship between maintenance phase and end user involvement on performance of consultative group on international agricultural research institutes in Kenya. Pearson correlation coefficient computed and tested at 5\% significance level. The results indicate that there is a positive relationship $(\mathrm{r}=0.656)$ between maintenance phase and end user involvement on performance of consultative group on international agricultural research institutes in Kenya. In addition, the researcher found the relationship to be statistically significant at 5\% level $(\mathrm{p}=0.000,<0.05)$. Hence, it is evident that all the independent variables could explain the changes in end user involvement on performance of consultative group on international agricultural research institutes in Kenya, on the basis of the correlation analysis. 
International Journal of Supply Chain and Logistics

ISSSN 2520-3983 (Online)

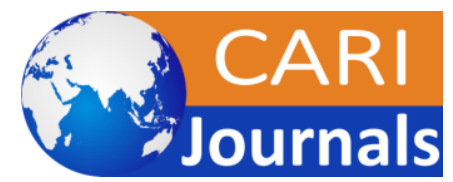

Vol. 4, Issue No.1, pp 70 - 92, 2020

www.carijournals.org

Table 10: Summary of Pearson's Correlations

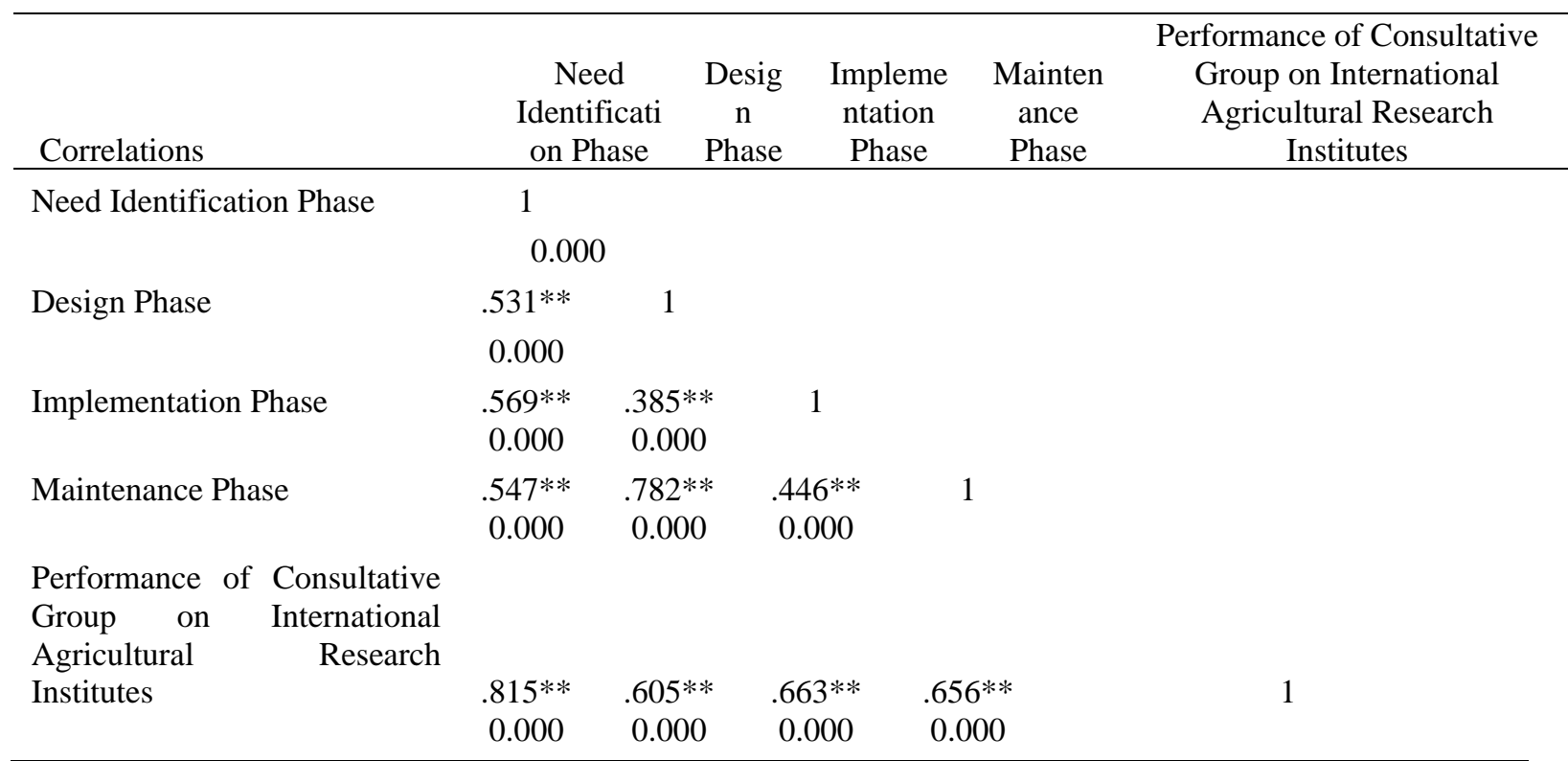

** Correlation is significant at the 0.05 level (2-tailed).

\subsection{Regression Analysis}

In this study multivariate regression analysis was used to determine the significance of the relationship between the dependent variable and all the independent variables pooled together. Regression analysis was conducted to find the proportion in the dependent variable (end user involvement) which can be predicted from the independent variables (need identification phase, design phase, implementation phase, maintenance phase).

Table 11 presents the regression coefficient of independent variables against dependent variable. The results of regression analysis revealed there is a significant positive relationship between dependent variable and the independent variable. The independent variables reported $R$ value of 0.876 indicating that there is perfect relationship between dependent variable and independent variables. R square value of 0.768 means that $76.8 \%$ of the corresponding variation in Performance of Consultative Group on International Agricultural Research Institutes can be explained or predicted by (need identification phase, design phase, implementation phase, maintenance phase) which indicated that the model fitted the study data. The results of regression analysis revealed that there was a significant positive relationship between dependent variable and independent variable at $(\beta=0.761), \mathrm{p}=0.000<0.05)$. 
International Journal of Supply Chain and Logistics

ISSSN 2520-3983 (Online)

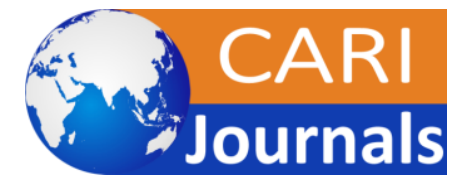

Vol. 4, Issue No.1, pp 70 - 92, 2020

www.carijournals.org

Table 11: Model Summary

\begin{tabular}{lllll}
\hline Model & R & R Square & Adjusted R Square & $\begin{array}{l}\text { Std. Error of the } \\
\text { Estimate }\end{array}$ \\
\hline 1 & $.876^{\mathrm{a}}$ & .768 & .762 & .112 \\
\hline
\end{tabular}

Predictors: (Constant), Need Identification Phase, Design Phase, Implementation Phase, Maintenance Phase

Dependent Variable: Performance of Consultative Group on International Agricultural Research Institutes

Table 12: ANOVA

\begin{tabular}{llccccc}
\hline Model & & $\begin{array}{c}\text { Sum of } \\
\text { Squares }\end{array}$ & df & Mean Square & F & Sig. \\
\hline 1 & Regression & 7.210 & 4 & 1.803 & 81.766 & $.000^{\mathrm{b}}$ \\
& Residual & 2.183 & 99 & 0.022 & & \\
& Total & 9.393 & 103 & & & \\
\hline
\end{tabular}

The significance value is 0.000 which is less than 0.05 thus the model is statistically significance in predicting how need identification phase, design phase, implementation phase, maintenance phase affect performance of consultative group on international agricultural research institutes in Kenya. The F critical at 5\% level of significance was 26.5 . Since F calculated which can be noted from the ANOVA table above is 81.8 which is greater than the $\mathrm{F}$ critical (value=26.5), this shows that the overall model was significant. The study therefore establishes that; need identification phase, design phase, implementation phase, maintenance phase affect performance of consultative group on international agricultural research institutes. These results agree with Njonjo, Rugo and Muigei (2011) results which discussed performance of consultative group on international agricultural research institutes.

Table 13: Coefficients of Determination

\begin{tabular}{|c|c|c|c|c|c|c|}
\hline \multirow[t]{2}{*}{ Mode } & & \multicolumn{2}{|c|}{$\begin{array}{l}\text { Unstandardized } \\
\text { Coefficients }\end{array}$} & \multirow{2}{*}{$\begin{array}{c}\begin{array}{c}\text { Standardized } \\
\text { Coefficients }\end{array} \\
\text { Beta } \\
\end{array}$} & \multirow[t]{2}{*}{$\mathbf{t}$} & \multirow[t]{2}{*}{ Sig. } \\
\hline & & $\beta$ & Std. Error & & & \\
\hline \multirow[t]{5}{*}{1} & (Constant) & 0.713 & 0.216 & & 3.298 & 0.001 \\
\hline & $\begin{array}{l}\text { Need Identification } \\
\text { Phase }\end{array}$ & 0.617 & 0.058 & 0.526 & 10.66 & 0.000 \\
\hline & Maintenance Phase & 0.085 & 0.026 & 0.203 & 3.301 & 0.001 \\
\hline & Implementation Phase & 0.062 & 0.012 & 0.245 & 5.167 & 0.000 \\
\hline & Design Phase & 0.038 & 0.032 & 0.072 & 1.208 & 0.020 \\
\hline
\end{tabular}

Predictors: (Constant), Need Identification Phase, Design Phase, Implementation Phase, Maintenance Phase 
International Journal of Supply Chain and Logistics

ISSSN 2520-3983 (Online)

Vol. 4, Issue No.1, pp 70 - 92, 2020

www.carijournals.org

Dependent Variable: Performance of Consultative Group on International Agricultural Research Institutes The research used a multiple regression model

$$
\mathbf{Y}=\boldsymbol{\beta}_{0}+\boldsymbol{\beta}_{1} \mathbf{X}_{1}+\boldsymbol{\beta}_{2} \mathbf{X}_{2}+\boldsymbol{\beta}_{3} \mathbf{X}_{3}+\boldsymbol{\beta}_{4} X_{4}+\mathcal{E}
$$

Where $\mathbf{Y}=$ Performance of Consultative Group on International Agricultural Research Institutes

$\boldsymbol{\beta}_{\mathbf{0}}=$ Constant

$\mathbf{X}_{\mathbf{1}}=$ Need Identification Phase

$\mathbf{X}_{2}=$ Design Phase

$\mathbf{X}_{\mathbf{3}}=$ Implementation Phase

$\mathbf{X}_{\mathbf{4}}=$ Maintenance Phase

$\boldsymbol{\varepsilon}=$ Error Term at $95 \%$ Confidence Level

The regression equation was;

$$
Y=0.713+0.617 X_{1}+0.085 X_{2}+0.062 X_{3}+0.038 X_{4}
$$

The regression equation above has established that taking all factors into account (need identification phase, design phase, implementation phase, maintenance phase) constant at zero, performance of consultative group on international agricultural research institutes will be an index of 0.713 . The findings presented also shows that taking all other independent variables at zero, a unit increase in need identification phase will lead to a 0.617 increase in performance of consultative group on international agricultural research institutes. The P-value was 0.000 which is less 0.05 and thus the relationship was significant.

The study also found that a unit increase in design phase will lead to a 0.038 increase in performance of consultative group on international agricultural research institutes. The P-value was 0.02 and thus the relationship was significant. In addition, the study found that a unit increase in implementation phase will lead to a 0.062 increase in the end user involvement on performance of consultative group on international agricultural research institutes. The P-value was 0.000 and thus the relationship was significant.

Lastly, the study found that maintenance phase will lead to a 0.085 decrease in the performance of consultative group on international agricultural research institutes. The P-value was 0.001 and hence the relationship was significant since the $\mathrm{p}$-value was lower than 0.05 . The findings of the study show that, need identification phase contributed most to performance of consultative group on international agricultural research institutes in Kenya. 
International Journal of Supply Chain and Logistics

ISSSN 2520-3983 (Online)

Vol. 4, Issue No.1, pp 70 - 92, 2020

$\underline{\text { www.carijournals.org }}$

\subsection{SUMMARY, CONCLUSION AND RECOMMENDATIONS}

\subsection{Summary of the Findings}

The study endeared to determine the influence of end user involvement on performance of consultative group on international agricultural research institutes in Kenya. The regression results revealed that the factors identified in the study, that is, need identification phase, design phase, implementation phase and maintenance phase combined could explain approximately $76.8 \%$ of the variations in the end user involvement on performance of consultative group on international agricultural research institutes. The other $23.2 \%$ may be attributed to other strategies not explained by the model or the variables.

From inferential statistics, a positive correlation is seen between each predictor variable and end user involvement on performance of consultative group on international agricultural research institutes. The strongest correlation was established between need identification phase and on performance of consultative group on international agricultural research institutes. All the independent variables were found to have a statistically significant association with the dependent variable at $95 \%$ level of confidence.

\subsection{Conclusion}

Based on the study findings, the study concludes that end user involvement influence on performance of consultative group on international agricultural research institutes can be improved by need identification phase, design phase, implementation phase and maintenance phase.

\subsection{Recommendations}

Finally, the study recommended that institutions should embrace need identification phase, design phase, implementation phase and maintenance phase so as to improve performance of consultative group on international agricultural research institutes and further researches should to be carried out in other institutions to find out if the same results can be obtained.

\section{REFERENCES}

Armstrong, M., \& Baron, A. (2014). Managing performance: performance management in action. London: Chartered Institute of Personnel and Development.

Balogun, M.J. (2008). Performance Management and Agency Governance for Africa Development: The search for common cause on Excellence in the Public Service. UNCEA, Addis Ababa.

Bolumole, Y. (2011). The Supply Chain Role of Third-Party end user involvement Providers. International Journal ofend user involvement Management, 12(2), 87-102.

Bourlakis, C., \& Bourlakis, M. (2015). Information technology safeguards, end user involvement asset specificity and fourth-partyend user involvement network creation in the food retail chain, The Journal of Business \& Industrial Marketing, 20 (2), 88-99. 
International Journal of Supply Chain and Logistics

ISSSN 2520-3983 (Online)

Vol. 4, Issue No.1, pp 70 - 92, 2020

www.carijournals.org

Bowersox, J., Closs, J., \& Cooper, M. (2010). Supply Chainend user involvement Management (3rd Ed); Boston, Mass: McGraw-Hill.

Chang, W., Chiang, M., \& Pai, Y. (2012). Cooperative Strategy in Supply Chain Networks. International Journal of Industrial Marketing Management 12 (1), 11-19.

Dean, A.M., \& Kiu, C. (2012). Performance monitoring and quality outcomes in contracted services, International Journal of Quality \& Reliability Management, 19 (4), 396-413

Evenett, J., \& Hoekman, M., (2014). International disciplines on government procurement: $a$ review of economic analyses and their implications, Centre for Economic Policy Research (CEPR)

Harland, C.M. (2009). Supply Chain Management: Relationships, Chains and Networks. British Journal of management, 21(14), 457-473

Heinrich, C.J. (2012). Outcomes-based performance management in the public sector: Implications for government accountability and influenceiveness. Public Administration Rev, 62(6), 712-725

Hendricks, K., \& Singhal, V. (2013). The Influence of Supply Chain glitches on Shareholder Wealth, Journal of Operations Management 45 (21), 501 - 522

Herbert, K., Juliana, H., Mikkola, W., \& Tage, S. (2013). Complementary theories to supply chain management. International Journal of Supply Chain Management 12(4), 284-296.

Kakwezi, P., \& Nyeko, S., (2010). Procurement Processes and Performance: Efficiency and Influenceiveness of the Procurement Function: Makerere University Press, NGO's coordination boardpala.

Kaufmann, M. (2008). Six questions on the cost of corruption with World Bank Institute of Global Governance Director: Danniel Kaufmann in News, the World Bank, Washington

Kombo, D., \& Tromp, D. (2011). Project and Thesis Writing, an introduction. Nairobi: Pauline Publications Africa.

Kothari, C.R. (2014). Research methodology: Methods and Techniques. 2 Ed, New Age International.

Kumar, R., \& Markeset, T. (2007). Development of performance-based service strategies for the oil and gas industry: a case study, Journal of Business \& Industrial Marketing, 22(4), 27280

Larry, H. (2013). Advanced Statistics in Research: Reading, Understanding, and Writing Up Data Analysis Results. Publisher: Shadow Finch Media LLC (January 7, 2013).

Lazear, E.P. (2010). Performance pay and productivity. Amer. Econom. Rev. 90(5), 1346-1361.

Malta, V., Schapper, R., Calvo-Gonzale, O., \& Berroa, D. (2011). Old Rules, New realities: Are existing public procurement systems addressing current and future needs? Washington, D.C.: The World Bank. 
International Journal of Supply Chain and Logistics

ISSSN 2520-3983 (Online)

Vol. 4, Issue No.1, pp 70 - 92, 2020

www.carijournals.org

Mohan, G. (2010). Participatory Development. In Desai, Vandana and Potter, Rob eds. The Arnold Companion to development studies. London, UK: Hodder.

Mukhopadhyay, S.K., \& Setaputra R., (2016). “The Role as the Reverse Logistic Integrator", International Journal of Physical Distribution \&end user involvement Management, 36(9), 716-729

Murphy, P., \& Poist, R. (2010). Third Partyend user involvement: Some user versus provider perspectives. Journal of Business end user involvement, 21 (1), 121-34

Narayanan, V., \& Raman, A. (2014). Aligning incentives in supply chains. Harvard Business Review, 82(11), 94-102.

Neuman, W.L. (2010). Social Research Methods: Qualitative and Quantitative Approaches (Fourth Edition ed.). Boston.

Ngechu, M. (2009). Understanding the Research Process and Methods. An Introduction to Research Methods. Acts press, Nairobi

Ngugi, J.K., \& Mugo, H.W. (2012). Internal factors affecting procurement process of supplies in the public sector; a survey of Kenya government ministries. Paper presented at 5th International Public Procurement Conference was held in Seattle, USA.

Ngyao, I., \& Yip, N. (2009). "Identifying risk and its impact on contracting through a benefit based-model framework in business to business contracting: A case of the defense industry", paper presented at the CIRP Industrial Product-Service Systems (IPS2) Conference

OECD (2009). Performance Contracting: Lessons from Performance Contracting Case Studies A framework for Private sector Performance Contracting. Paris: Public Management Service/ Public Management.

OECD. (2008). Integrity in Public Procurement: Mapping out Good Practices for Integrity and Corruption Resistance in Public Procurement.

Panayidis, P., \& Meko, S. (2013).end user involvement Service Provider - Client Relationships. Transportation Research, 5 (41), 179-200

Park, J., Shin, K., Chang, T.W., \& Park, J. (2010). An integrative framework for supplier relationship management. International Journal of Industrial Management \& Data Systems, 110 (4), 495-515.

Parkhe, A. (2013). Strategic alliance structuring: a game theoretic and transaction cost examination of inter-firm cooperation. Academy of Management Journal, 36(4), 794-829.

Patron, M. (2012). Qualitative Research and Evaluation Method (3ed.). London: Sage Publication Performance.

PPOA. (2007). Assessing Procurement Systems in Kenya Report. Nairobi: Public Oversight Authority. 
International Journal of Supply Chain and Logistics

ISSSN 2520-3983 (Online)

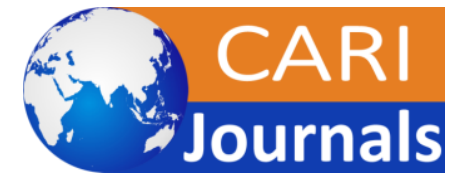

Vol. 4, Issue No.1, pp 70 - 92, 2020

www.carijournals.org

Rotich, L.M. (2011). Influence of Planning on Procurement Performance in the Kenya Public Financial Sector.

Straight, R.L. (2010). "Performance-based contracting: results, performance standards, incentives”, paper presented at the Annual International Supply Management Conference,

Sylvia, J.H. (2008). The role of technical skill in perceptions of managerial performance. Journal of Management Development. 27(3), 275-290. Emerald Group Publishing Limited 